\title{
Pengaruh Penerapan Teknik Data Mining Dalam Menemukan Kriteria Kelayakan Penerima Bonus Tambahan Pegawai Menggunakan Algoritma C4.5
}

\author{
Wulan Nadia Puri Heriani' ${ }^{1}$, Irfan Sudahri Damanik ${ }^{2}$, M. Fauzan ${ }^{3}$ \\ STIKOM Tunas Bangsa Pematangsiantar \\ Jl. Jend. Sudirman Blok A No. 1-3 Pematangsiantar, 0622-7436800/062222431 \\ wulannadiapuriheriani20@gmail.com, irfansudahri@gmail.com,m.fauzan@stikomtb.ac.id
}

\begin{abstract}
Employees are components where the company's future depends on how the performance and contributions are given. Employee performance can also be determined by how the company treats employees, both in terms of awards to each employee, work location determination and salary. Every employee who works in a company basically has one reason, namely getting a decent salary in accordance with his field. Here the company takes the initiative to provide additional bonuses to each decent employee. Therefore companies need to know the criteria that greatly influence the feasibility of giving bonuses so that companies can more easily draw conclusions. This research will help companies use data mining techniques with the c4.5 algorithm. Data mining is a series of processes to explore values in information that might not be known manually. C4.5 algorithm is used to make a decision tree that will display the results of the problem under study.
\end{abstract}

Keywords: Data Mining, C4.5 Algorithm, Decision Tree

Abstrak- Pegawai adalah komponen dimana masa depan perusahaan bergantung oleh bagaimana kinerja dan kontribusi yang diberikan. Kinerja pegawai dapat ditentukan pula dengan bagaimana perusahaan memperlakukan pegawai, baik dari segi penghargaan kepada masing-masing pegawai, penetapan lokasi kerja maupun gaji. Setiap pegawai yang bekerja di suatu perusahaan pada dasarnya memiliki satu alasan yaitu mendapatkan gaji yang layak sesuai dengan bidangnya. Disini perusahaan berinisiatif untuk memberikan bonus tambahan kepada masing-masing pegawai yang layak. Oleh karena itu perusahaan perlu mengetahui kriteria yang sangat berpengaruh terhadap kelayakan pemberian bonus agar perusahaan dapat lebih mudah dalam mengambil kesimpulan. Penelitian ini akan membantu perusahaan menggunakan teknik data mining dengan algoritma C4.5. Data mining merupakan serangkaian proses untuk menggali nilai dalam informasi yang mungkin tidak diketahui secara manual. Algoritma C4.5 digunakan untuk membuat pohon keputusan yang akan menampilkan hasil dari masalah yang diteliti.

Kata Kunci : Data Mining, Algoritma C45, Decision Tree

\section{PENDAHULUAN}

Di dalam suatu perusahaan komponen utama adalah pegawai, kinerja pegawai sangat mempengaruhi masa depan perusahaan. Apabila pegawai tidak memberikan kinerja yang baik maka perusahaan juga akan mengalami proses yang lama untuk maju. Begitu juga dengan pegawai yang mulai malas dalam bekerja dikarenakan upah yang diterima tidak sesuai atau tidak bertambah. Hal ini akan sangat mempengaruhi kemajuan dari perusahaan, dikarenakan kinerja dari pegawai tidak maksimal. Dari masalah yang muncul, perusahaan berinisiatif untuk 
memberikan bonus tambahan kepada pegawai setiap bulan. Kriteria penilaian pegawai telah disusun oleh manager perusahaan diantarnya masa kerja, kehadiran kinerja dan hasil pencapaian. Kemudian untuk mempermudah pemberian bonus, akan dicari kriteria mana yang sangat mempengaruhi terhadap pemberian bonus pegawai. Kebijakan ini dilaksanakan guna meningkatkan kualitas dan loyalitas dari setiap pegawai. Maka dalam tulisan ini akan diteliti kriteria yang sangat berpengaruh dalam pemberian bonus tambahan pegawai.Dilangsir dari penelitian terkait yang memiliki kesamaan berupa tahapan perhitungan serta pencarian data. "Dari data yang ada dapat digunakan untuk dilakukan pengolahan data. Salah satu teknik pengolahan data yang dapat digunakan dalam proses pemecahan masalah adalah klasifikasi. Klasifikasi adalah teknik pengolahan data yang membagi objek menjadi beberapa kelas sesuai dengan jumlah kelas yang diinginkan. Dan menggunakan Algoritma C4.5 dalam proses pengklasifikasi-annya. Algoritma ini dapat menentukan apakah hasil menunjukkan pembagian ya atau tidak"[1].

\section{METODOLOGI PENELITIAN}

Penelitian ini menggunakan algoritma C4.5 yang merupakan bagian dari teknik data minin. "Algoritma C4.5 merupakan salah satu metode yang dapat menganalisis data dalam jumlah yang banyak menggunakan konsep entropy dan gain. Dengan algoritma tersebut dibuatkan analisis pohon keputusan untuk mengukur kriteria terbaik dan menghasilkan angka akurasi"[2]. Menggunakan rancangan penelitian ditunjukaan pada gambar dibawah ini :

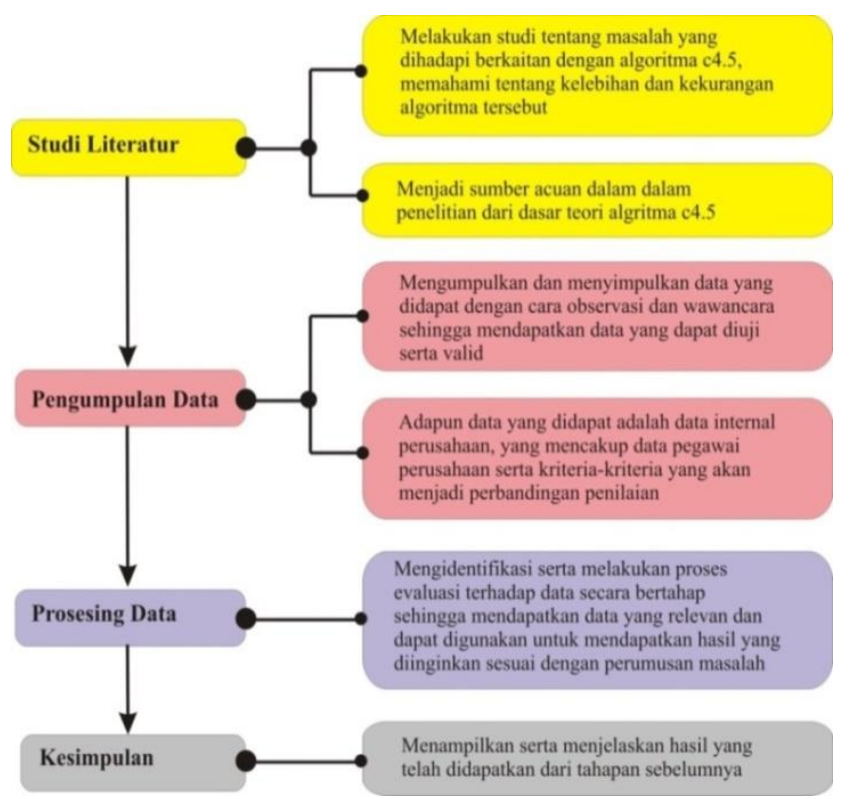

Gambar 1. Rancangan Penelitian

\subsection{Perancangan Penelitian}

Rancangan penelitian merupakan bagian yang berisi rancangan atau alir sistem. Rancangan ini menampilkan tahapan penyelesaian penelitian dengan menggunakan algoritma yang telah disebutkan. Dengan adanya rancangan penelitian ini akan memudahkan dalam pencarian hasil yang diinginkan. Berikut adalah rancangan penelitian pada penelitian ini berdasarkan algoritma C4.5. 


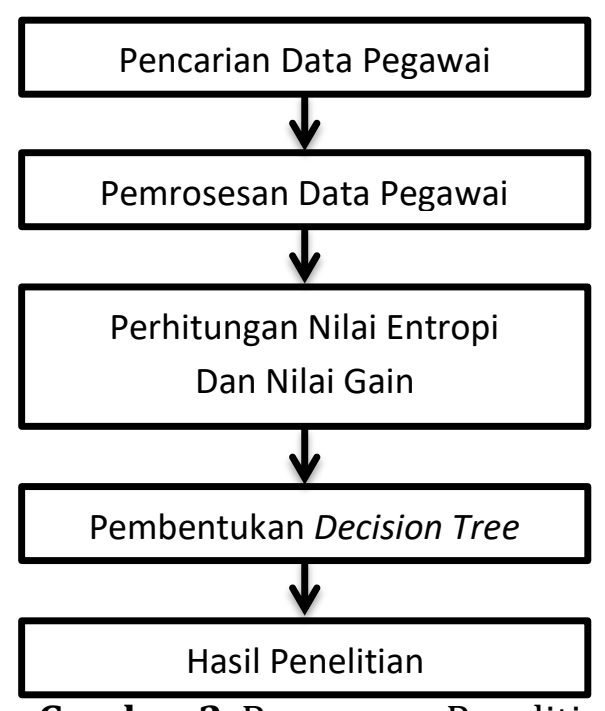

Gambar 2. Rancangan Penelitian

1. Pencarian Data Pegawai.

Data diambil dari perusahaan yang bersangkutan mengenai data-data pegawai yang dibutuhkan dalam penelitian. Berikut disajikan data mentah pegawai perusahaan yang akan menjadi objek penelitian.

2. Pemrosesan Data Pegawai

Proses data kuantitatif menjadi bentuk tabel sehingga dapat dengan mudah untuk diteliti dan digunakan. Data kuantitatif selanjutnya akan dievaluasi sehingga mendapatkan data yang siap untuk diproses.

3. Perhitungan Nilai Entropy dan Nilai Gain

Data yang telah di proses selanjutnya akan dicari nilai entropy dan nilai gain dengan menggunkan rumus yang telah disediakan, yang mana telah dijabarkan pada bab 2 karya ilmiah ini.

4. Pembentuka Decision Tree

Setelah didapat nilai entropy dan nilai gain, selanjutnya akan dibentuk diagram berupa pohon atau sering disebut decision tree.

5. Hasil Penelitian

Hasil dari penelitian dapat dilihat langsung dari bentuk decision tree.

\subsection{Rapidminer}

"Rapidminer merupakan software yang berdiri sendiri untuk analisis data dan sebagai mesin data mining yang dapat diitegrasikan pada produknya sendiri. Rapidminer ditulis dengan menggunakan bahasa java sehingga dapat bekerja di semua sistem operasi. Rapidminer menyediakan GUI (Graphic User Iterface) untuk merancang sebuah pipeline analitis. GUI ini akan menghasilkan file XML (Extensible Markup Language) yang mendefenisikan proses analitis keinginan pengguna untuk diterapkan ke data. File ini kemudian dibaca oleh Rapidminer untuk menjalankan analis secara otomatis"[3]. 


\section{HASIL DAN PEMBAHASAN}

\subsection{Pencarian Data Pegawai}

Berikut data yang telah didapat yang berupa data mentah yang akan diteliti :

Tabel 1. Data Pegawai dan Kriteria Penilaian

\begin{tabular}{|l|l|l|l|l|l|l|}
\hline No & Nama & Masa Kerja & Kehadiran & Kinerja & Hasil & Layak \\
\hline 1 & Ali Aridho Dalimunthe & 5 Tahun & Baik & Sangat Baik & Sangat Baik & Ya \\
\hline 2 & Fitse Simbolon & 1 Tahun & Sangat Baik & Sangat Baik & Sangat Baik & Ya \\
\hline 3 & Hevin Chandra & 2 Tahun & Kurang Baik & Baik & Kurang Baik & Tidak \\
\hline 4 & Indah Safitri Sinaga & 2 Tahun & Baik & Baik & Baik & Ya \\
\hline 5 & Lisa Anderia & 10 Tahun & Kurang Baik & Kurang Baik & Baik & Tidak \\
\hline 6 & M.Abdur Rahman & 4 Tahun & Baik & Baik & Baik & Ya \\
\hline 7 & M.Royhan Nasution & 1 Tahun & Baik & Baik & Kurang Baik & Tidak \\
\hline 8 & Rizky Paradillah Sandy & 6 Tahun & Baik & Kurang Baik & Baik & Tidak \\
\hline 9 & Roynaldi Simare-mare & 2 Tahun & Baik & Baik & Kurang Baik & Tidak \\
\hline 10 & Ruliani Saragih & 5 Tahun & Baik & Sangat Baik & Sangat Baik & Ya \\
\hline 11 & Suhariadi & 2 Tahun & Sangat Baik & Baik & Baik & Ya \\
\hline
\end{tabular}

\subsection{Pemrosesan Data Pegawai}

Data yang telah didapat selanjutnya diproses sehingga mendapatkan data yang siap untuk digunakan :

Tabel 2. Data Proses

\begin{tabular}{|l|l|l|l|l|}
\hline Masa Kerja & Kehadiran & Kinerja & Hasil & Layak \\
\hline Baru & Sangat Baik & Sangat Baik & Sangat Baik & Ya \\
\hline Baru & Kurang Baik & Baik & Kurang Baik & Tidak \\
\hline Baru & Baik & Baik & Baik & Ya \\
\hline Baru & Baik & Baik & Kurang Baik & Tidak \\
\hline Baru & Baik & Baik & Kurang Baik & Tidak \\
\hline Baru & Sangat Baik & Baik & Baik & Ya \\
\hline Lama & Baik & Sangat Baik & Sangat Baik & Ya \\
\hline Lama & Kurang Baik & Kurang Baik & Baik & Tidak \\
\hline Lama & Baik & Baik & Baik & Ya \\
\hline Lama & Baik & Kurang Baik & Baik & Tidak \\
\hline Lama & Baik & Sangat Baik & Sangat Baik & Ya \\
\hline
\end{tabular}

\subsection{Perhitungan Nilai Entrophy dan Nilai Gain}

Perhitungan nilai entrophy dan gain dilakukan dengan menggunkan rumus sebagai berikut :

$$
\begin{aligned}
\text { Entrophy [Total }] & =(-(6 / 11) *(\log 2(6 / 11))+(-(5 / 11) *(\log 2(5 / 11)) \\
& =0,9940302114
\end{aligned}
$$

Kriteria : Masa kerja, kehadiran, kinerja, hasil.

Menghitung entropy dan gain masa kerja :

Entrophy [Masa kerja-baru] $=(-(3 / 6) *(\log 2(3 / 6))+(-(3 / 6) *(\log 2(3 / 6))$

$$
=1
$$

Entrophy [Masa kerja-lama] $=(-(3 / 5) *(\log 2(3 / 5))+(-(2 / 5) *(\log 2(2 / 5))$

$$
=0,9709505944
$$

Gain $[$ Masa kerja] $=0,9940302114-((6 / 11) * 1)+((5 / 11) * 0,9709505944)$

$$
=0,0072344867
$$


Menghitung entrophy dan gain kehadiran :

Entrophy [Kehadiran-sangat baik] $=0$

Entrophy [Kehadiran-Baik] $\quad=(-(4 / 7) *(\log 2(4 / 7))+(-(3 / 7) *(\log 23 / 7))$

Entrophy [Kehadiran-kurang baik] $=0$

$$
=0,9852281360
$$

Gain [Kehadiran] $=0,9940302114-((2 / 11) * 0)+((7 / 11) * 0,9852281360)+$ $((2 / 11) * 0)=0,3670668521$

Menghitung entrophy dan gain kinerja :

Entrophy [Kinerja-sangat baik] $\quad=0$

Entrophy [Kinerja-baik] $\quad=(-(3 / 6) *(\log 2(3 / 6))+(-(3 / 6) *(\log 2(3 / 6))$

$$
=1
$$

Entrophy [Kinerja-Kurang baik] $=0$

Gain $[$ Kinerja] $\quad=0,9940302114-((3 / 11) * 0)+((6 / 11) * 1+((2 / 11 * 0)$

$$
=0,448575666
$$

Menghitung entrophy dan gain hasil :

Entrophy [Hasil-sangat baik] $=0$

Entrophy [Hasil-baik] $\quad=(-(3 / 5) *(\log 2(3 / 5))+(-(2 / 5) *(\log 2(2 / 5))$

Entrophy [Hasil-kurang baik] $=0$

$$
=0,9709505944
$$

Gain $[$ Hasil] $\quad=0,9940302114-((3 / 11) * 0)+((5 / 11) * 0,9709505944)+$

$$
((3 / 11) * 0)=0.552689032
$$

Selanjutnya jika hasil masih dapat dilakukan perhitungan maka ulangi proses dalam setiap cabang sehingga semua kasus dalam cabang memiliki kelas yang sama, mengulangi

\begin{tabular}{|c|c|c|c|c|c|c|c|}
\hline Node & Kriteria & Nilai & Sum & Ya & Tidak & Entrophy & Gain \\
\hline \multirow[t]{16}{*}{1} & Total & & 11 & 6 & 5 & 0,9940302114 & \\
\hline & \multicolumn{5}{|c|}{ Masa Kerja } & & 0,0072344867 \\
\hline & & Baru & 6 & 3 & 3 & 0,9709505944 & \\
\hline & & Lama & 5 & 3 & 2 & 0,0072344867 & \\
\hline & \multicolumn{6}{|l|}{ Kehadiran } & 0,3670668521 \\
\hline & & Sangat Baik & 2 & 2 & 0 & 0 & \\
\hline & & Baik & 7 & 4 & 3 & 0,9852281360 & \\
\hline & & Kurang Baik & 2 & 0 & 2 & 0 & \\
\hline & \multicolumn{6}{|l|}{ Kinerja } & 0,448575666 \\
\hline & & Sangat Baik & 3 & 3 & 0 & 0 & \\
\hline & & Baik & 6 & 3 & 3 & 1 & \\
\hline & & Kurang Baik & 2 & 2 & 0 & 0 & \\
\hline & \multicolumn{6}{|l|}{ Hasil } & 0,552689032 \\
\hline & & Sangat Baik & 3 & 3 & 0 & 0 & \\
\hline & & Baik & 5 & 3 & 2 & 0,970950944 & \\
\hline & & Kurang Baik & 3 & 0 & 3 & 0 & \\
\hline
\end{tabular}
semua proses perhitungan gain tertinggi untuk masing-masing cabang kasus sampai tidak bisa lagi dilakukan proses perhitungan. Pada perhitungan diatas ditunjukkan pada tabel node dibawah ini :

Tabel 3. Perhitugan Node 1

Pada tabel diatas menunjukkan kriteria yang memiliki nilai gain tertinggi yaitu kriteria hasil. Dan memiliki entrophy 0 pada nilai sangat baik dan kurang baik, tetapi pada 
nilai baik belum menunjukan entrophy 0 makaperlu dilakukan perulangan perhitungan sehingga hasil yang didapat menunjukkan nilai 0. Perhitungan akan dilakukan sama dengan perhitungan entrophy dan gain sebelumnya dan mendapatkan hasil sebagai berikut :

Tabel 4. Perhitungan Node 1.1

\begin{tabular}{|l|l|l|l|l|l|l|l|}
\hline Node & Kriteria & Nilai & Sum & Ya & Tidak & Entrophy & Gain \\
\hline 1.1 & Hasil & Baik & 5 & 3 & 2 & 0,9708505944 & \\
\hline & Masa Kerja \\
\hline & Baru & 2 & 2 & 0 & 0 & 0,4199730940 \\
\hline & & Lama & 3 & 1 & 2 & 0,9182958340 & \\
\hline & Kehadiran \\
\hline & Sangat Baik & 1 & 1 & 0 & 0 & 0,4199730940 \\
\hline & Baik & 3 & 2 & 1 & 0,9182958340 & \\
\hline & Kurang Baik & 1 & 0 & 1 & 0 & \\
\hline & Kinerja & Baik & 3 & 3 & 0 & 0 & 0,9709505944 \\
\hline & & Kurang Baik & 2 & 0 & 2 & 0 & \\
\hline & &
\end{tabular}

\subsection{Pembentukan Decision Tree}

Dari perhitungan diatas didapatkan hasil berupa pohon keputusan sebagai berikut :

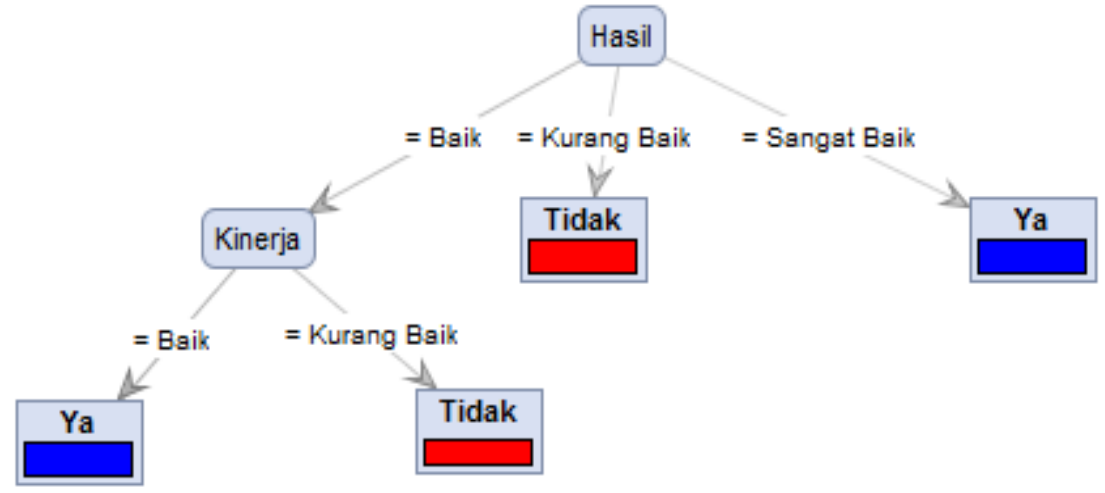

Gambar 3. Decision Tree

\subsection{Hasil Penelitian}

Menunjukan hasil yang dapat dilihat berupa rule mode dari pohon keputusan sebagai berikut :

Hasil $=$ Baik

Hasil $=$ Kurang Baik $:$ Tidak $\{$ Ya $=0$, Tidak $=3\}$

Hasil $=$ Sangat Baik $:$ Ya $\{Y a=3$, Tidak $=0\}$

\section{KESIMPULAN}

Berdasarkan penelitian yang telah dilakukan tentang menemukan kriteria dalam kelayakan pemberian bonus tambahan pegawai ini diperoleh beberapa kesimpulan antara lain :

a. Hasil yang di dapat dari penelitian ini yang berjudul pengaruh penerapan teknik data mining dalam menemukan kriteria kelayakan penerima bonus tambahan pegawai dengan menggunakan algoritma c4.5 menampilkan hasil bahwa yang 
menjadi kriteria terbaik yang dapat digunakan dalah memutuskan pegawai yang layak mendapatkan bonus tambahan adalah kiteria kinerja, dimana dalam kriteria ini terdapat beberapa nilai yaitu sangat baik, baik, dan kurang baik. Pada pohon keputusan menampilkan kriteria kinerja nilai baik berhak mendapatkan bonus tambahan sedangkan kriteria kinerja bernilai kurang baik tidak berhak mendapatkan bonus tambahan serta bernilai sangat baik termasuk berhak dalam mendapatkan bonus tambahan pegawai.

b. Pemilihan teknik data mining adalah salah satu cara yang tepat dalam menemukan kriteria kelayakan penerima bonus tambahan pegawai karena dapat mempengaruhi proses dari penelitian sehingga hasil yang didapat sesuai dan dapat dibuktikan.

c. Peggunaan algoritma c4.5. dapat membantu dalam medapatkan hasil berupa pohon keputusan melalui perhitungan nilai entrophy dan gain.

d. Hasil yang diperoleh dari perhitungan manual algoritma dapat dibuktikan dengan tools rapidminer yang menampilakan hasil berupa pohon keputusan yang memiliki kesamaan baik tampilan ataupun isi.

\section{DAFTAR PUSTAKA}

[1] M. F. Arifin and D. Fitrianah, "Penerapan Algoritma Klasifikasi C4.5 Dalam Rekomendasi Penerimaan Mitra Penjualan Studi Kasus : PT Atria Artha Persada," InComTech, vol. 8, no. 2, pp. 87-102, 2018.

[2] T. B. Ayuni Asistyasari1, "Analisis Penerimaan Karyawan Posisi Field Collector Menggunakan Algoritma C4.5 Pada Pt. Prismas Jamintara Jakarta," J. Ilmu Pengetah. Dan Teknol. Komput., vol. 2, no. 2, pp. 1-6, 2017.

[3] G. Syahputra, "Penerapan Algoritma C4 . 5 Dalam Analisa Kelayakan Penerima Bonus Tahunan Pegawai ( Studi Kasus: PT . Multi Pratama Nauli Medan )," J. Mantik Penusa, vol. 16 , no. 2, 2015

[4] A. P. Windarto, L. S. Dewi, and D. Hartama, "Implementation of Artificial Intelligence in Predicting the Value of Indonesian Oil and Gas Exports With BP Algorithm," International Journal of Recent Trends in Engineering \& Research (IJRTER), vol. 3, no. 10, pp. 1-12, 2017.

[5] I. S. Sulistyorini, M. Edwin, and A. S. Arung, "ANALISIS KUALITAS AIR PADA SUMBER MATA AIR DI KECAMATAN KARANGAN DAN KALIORANG KABUPATEN KUTAI TIMUR," Jurnal Hutan Tropis, vol. 4, no. 1, pp. 64-76, 2016. 